\title{
Oxygen Uptake Rate and Carbon dioxide Evolution Rate on the Fermentation Process of Cocoa Beans (Theobroma Cacao L.)
}

\author{
Sri Hartuti $^{\mathrm{a}}$, Nursigit Bintoro ${ }^{\mathrm{b}, 1}$, Joko Nugroho Wahyu Karyadi ${ }^{\mathrm{b}, 2}$, Yudi Pranoto ${ }^{\mathrm{c}}$ \\ ${ }^{a}$ Department of Agricultural Engineering, Universitas Syiah Kuala, Banda Aceh, 23111, Indonesia \\ E-mail: sri.hartuti@unsyiah.ac.id \\ ${ }^{b}$ Department of Agricultural and Biosystem Engineering, Universitas Gadjah Mada., Yogyakarta 55281, Indonesia. \\ E-Mail: ${ }^{1}$ nursigit@ugm.ac.id; ${ }^{2}$ jknugroho@ugm.ac.id \\ ${ }^{c}$ Department of Food and Agricultural Product Technology, Universitas Gadjah Mada, Yogyakarta 55281, Indonesia \\ E-Mail:pranoto@ugm.ac.id
}

\begin{abstract}
Fermentation is one of the most critical stages in the postharvest handling process of cocoa beans. Temperature changes during the fermentation process characterize the success of the cocoa bean fermentation process. In general, aeration conditions during the fermentation process effects changes in fermentation air temperature. This study aims to determine cumulative oxygen uptake and cumulative carbon dioxide evolution during cocoa bean fermentation. Fermenter equipped with a controlled system of air temperatures and aeration rates was used to determine changes in oxygen uptake rate and carbon dioxide evolution rate during the fermentation process. The variables observed were including: length of pod storage time before fermentation $\left(X_{1}\right.$; days $)$, aeration rate $\left(\mathrm{X}_{2} ;\right.$ l.min $\left.^{-1}\right)$, and fermenter temperature $\left(\mathrm{X}_{3} ;{ }^{\circ} \mathrm{C}\right)$. Response surface methodology was used to determine the relationship between cumulative oxygen uptake as well as cumulative carbon dioxide evolution and the observed variables $\left(X_{1}, X_{2}, X_{3}\right)$ The results shows that cumulative oxygen uptake and cumulative carbon dioxide evolution obtained in various treatments during the fermentation process are consecutive: 6.66-34.29 $\mathrm{g} \mathrm{O}_{2} \mathrm{~kg}_{\mathrm{vs}}{ }^{-1}$ and 12.15-50.97 $\mathrm{g} \mathrm{CO}_{2} \mathrm{~kg}_{\mathrm{vs}}{ }^{-1}$. Based on the variance analysis of response surface methodology, $R^{2}$ value of the cumulative oxygen uptake is about $88.1 \%$, while $R^{2}$ value of the cumulative carbon dioxide evolution value is about $87.3 \%$. The highest amount of oxygen consumption and carbon dioxide production was obtained at $X_{1}=5$ days, $X_{2}=$ 0.25- 0.4 l.min ${ }^{-1}$, and $\mathrm{X}_{3} \leq 50^{\circ} \mathrm{C}$.
\end{abstract}

Keywords - oxygen uptake; carbon dioxide evolution; fermentation cacao beans; aeration rate.

\section{INTRODUCTION}

The fermentation of cocoa beans is one of the critical processes that must be performed to obtain high-quality chocolate products [1]-[3]. Imperfectly fermented or unfermented cocoa beans will have a distinctive lowchocolate flavor when roasted and even overwhelmed by the dominant bitter and spicy taste [4], [5]. Cocoa bean fermentation aims to form a distinctive flavor of chocolate, hollow and brown pieces of seeds, reduce the bitter and septic taste in cocoa beans, and produce seeds of good quality and aroma [6].

The correct cocoa fermentation process is an essential step in producing high-quality chocolate [6]. Even the fermentation process is considered very important because it can increase biochemical changes and the concentration of flavor precursors in cocoa beans [7]-[9]. The success of the cocoa bean fermentation process is generally influenced by a variety of factors, including cacao ripening, fermentation equipment, the amount of cocoa, changes in air temperature, and stirring or reversal of cocoa beans. Increased fermentation air temperature will occur optimally if the fermentation air needs are met properly. It is known that during the fermentation process there is generally a temperature change between $25-52^{\circ} \mathrm{C}$ [10]-[12]. Aeration factor is the main thing that must be considered in a good fermenter design to optimize the physical aspects of the fermentation process [5].

Aeration and changes in air temperature during fermentation affect the success of the fermentation process so that the control of aeration and air temperature during the fermentation process needs to be done. The purpose of this study was to identify the effect of storing cocoa fruit before fermentation, as well as the effect of aeration control and fermenter air temperature on the amount of oxygen uptake and carbon dioxide evolution during the fermentation process of cocoa beans. 


\section{MATERIALS AND METHOD}

\section{A. Research Equipment and Materials}

The research equipment used in this study include a fermenter equipped with an air temperature control system, KOJIMA model RK1150 airflow meter, air pump, oxygen/carbon dioxide analyzer Quantek Model 902D instruments, Oxygen Meter DO5509, $\mathrm{CO}_{2}$ Meter G2028, and other supporting equipment. The material used in this study is cocoa fruit obtained from farmers' gardens in Tanen Hamlet, Hargobinangun Village, Pakem District, Sleman Regency, Yogyakarta, Indonesia. Cocoa samples were chosen with a uniform type and maturity level.

\section{B. The Working Principle of the Fermenter}

Fermentation was carried out using a reactor tube placed in a chamber equipped with an air temperature control system using a data logger and aeration system that refers to references [13]. Control of the air temperature outside and inside the reactor tube is carried out using a temperature sensor provided that the fermenter temperature is controlled continuously with variations of $40^{\circ} \mathrm{C}, 50^{\circ} \mathrm{C}$, and $60^{\circ} \mathrm{C}$ starting at 25 to 120 hours of fermentation.

\section{Cocoa Bean Fermentation Process}

Samples of harvested cocoa fruit are then stored in a pest and weed-free area at room temperature for 1, 5, and 9 days. Furthermore, $1 \mathrm{~kg}$ of cocoa beans which have been separated from the skin and placenta, is put into a tightly closed reactor tube, without the addition of air temperature and aeration for 24 hours. Furthermore, the air aeration rate and the temperature of the air inside the fermenter are set and given constantly on the second day until the end of the fermentation process (day 5). Aeration rate variations are given as $0.2 ; 0.3$; and 0.4 l.mnt- 1 , while variations in fermenter air temperature: $40{ }^{\circ} \mathrm{C}, 50{ }^{\circ} \mathrm{C}$, and $60{ }^{\circ} \mathrm{C}$. Some criteria for the condition of the cocoa beans before the fermentation process are listed in Table 1.

\section{TABLE I}

Conditions of CocoA BeAns Before The Fermentation Process

\begin{tabular}{|c|c|c|c|}
\hline $\begin{array}{c}\text { Storage of } \\
\text { cocoa fruit } \\
\text { (days) }\end{array}$ & $\begin{array}{c}\text { Initial moisture } \\
\text { content } \\
(\boldsymbol{\%})\end{array}$ & $\begin{array}{c}\text { Initial ash } \\
\text { content } \\
(\boldsymbol{\%})\end{array}$ & $\begin{array}{c}\text { Volatile } \\
\text { solid } \\
(\mathbf{k g})\end{array}$ \\
\hline 1 & 54.40 & 3.81 & 0.962 \\
\hline 5 & 51.79 & 4.06 & 0.960 \\
\hline 9 & 47.18 & 3.68 & 0.963 \\
\hline
\end{tabular}

D. Respiratory Rate of Cocoa Beans During the Fermentation Process

The measurement of the respiration rate during the cocoa bean fermentation process is carried out by continually flowing air into the reactor tube during fermentation. Respiration rate is calculated based on differences in the concentration of gas $\left(\mathrm{O}_{2}\right.$ and $\left.\mathrm{CO}_{2}\right)$ between the inlet and outlet when the system is in steady-state [14]. Respiratory system scheme for cocoa bean fermentation, as shown in Fig. 1.

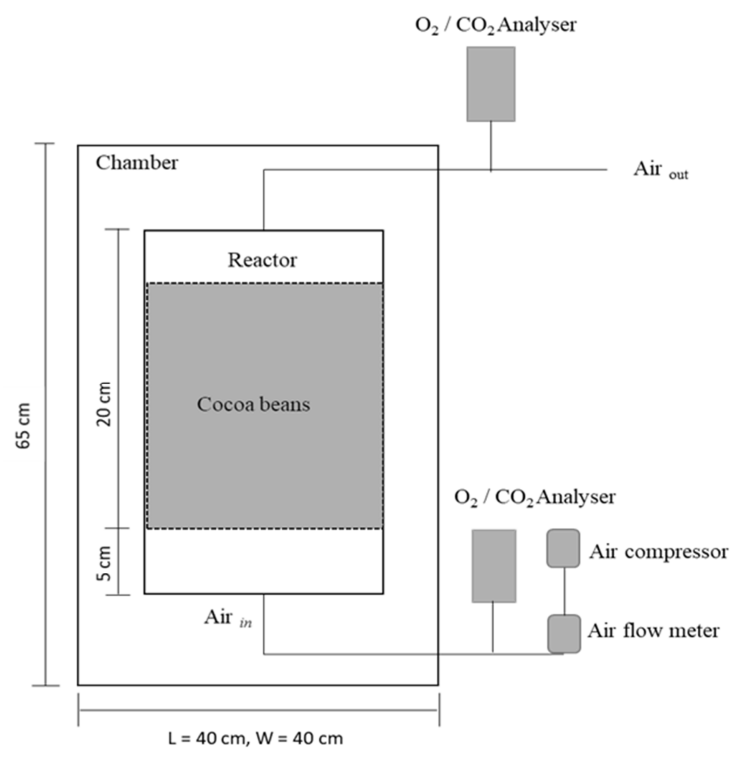

Fig. 1 Respiratory system in cocoa bean fermentation.

1) Oxygen Uptake Rate (OUR) Measurement: Measurement of the amount of oxygen consumption is carried out to determine the amount of oxygen demand during the fermentation process. Oxygen uptake rate (OUR) during the cocoa bean fermentation process is calculated using Eq. (1) and (2) [13].

$$
\begin{gathered}
C O_{2=}=\frac{\mathrm{MO}_{2} \mathrm{PCO}_{2} \mathrm{vol}}{100 R(273,15+T)} \\
O U R=\frac{Q\left(\mathrm{CO}_{\left.2 a-C \mathrm{CO}_{2}\right)}\right.}{V S_{0}}
\end{gathered}
$$

2) Carbon Dioxide Evolution Rate (CER) Measurement

$$
\begin{gathered}
C C O_{2}=\frac{\mathrm{MCO}_{2} \mathrm{PCCO}_{2 \mathrm{vol}}}{100 R(273,15+T)} \\
C E R=\frac{\left(\mathrm{CCO}_{2 a}-\mathrm{CCO}_{2}\right) x Q}{V S_{0}}
\end{gathered}
$$

\section{E. Analysis of Research Data}

The research consisted of 20 treatments. The data were analyzed using response surface methodology (RSM) to determine the effect of pod storage before fermentation $\left(\mathrm{X}_{1}\right)$, aeration rate $\left(\mathrm{X}_{2}\right)$, and fermenter temperature $\left(\mathrm{X}_{3}\right)$ on cumulative oxygen uptake and cumulative carbon dioxide evolution during the fermentation process. Experimental design, limits, and level of variables, as shown in Table 2.

TABLE II

LIMITATION AND VARIABLE LEVEL OF CHANGE/INDEPENDENT VARIABLES FOR COCOA BEAN FERMENTATION

\begin{tabular}{|l|c|c|c|}
\hline \multicolumn{1}{|c|}{ Variable $(\mathbf{X})$} & \multicolumn{3}{c|}{ Batasan dan Level } \\
\cline { 2 - 4 } & $\mathbf{- 1}$ & $\mathbf{0}$ & $\mathbf{+ 1}$ \\
\hline $\begin{array}{l}\text { Pod storage before fermentation, } \mathrm{X}_{1} \\
\text { (days), }\end{array}$ & 1 & 5 & 9 \\
\hline Aeration rate, $\mathrm{X}_{2}\left(1 . \mathrm{min}^{-1}\right)$ & 0.2 & 0.3 & 0.4 \\
\hline Fermenter temperature, $\mathrm{X}_{3}\left({ }^{\circ} \mathrm{C}\right)$ & 40 & 50 & 60 \\
\hline
\end{tabular}


The results of data analysis using RSM are produce mathematical equations [15], [16] as follows:

$$
Y=\beta_{0}+\beta_{1} X_{1}+\beta_{2} X_{2}+\beta_{3} X_{3}+\beta_{11} X_{1}^{2}+\beta_{22} X_{2}^{2}+\beta_{33} X_{3}^{2}+\beta_{12} X_{1} X_{2}+\beta_{13} X_{1} X_{3}+\beta_{23} X_{2} X_{3}
$$

\section{RESULTS AND DISCUSSION}

\section{A. Respiration Rate in Cocoa Beans Fermentation}

The results showed that the oxygen uptake rate (OUR) and carbon dioxide evolution rate (CER) values during the cocoa bean fermentation process, as shown in Fig. 2 and Fig. 3. The highest OUR and CER respiration rates were obtained on days 2 and 3 of the fermentation process. Then the value continues to decline until the end of the fermentation process. The increase in OUR during fermentation is accompanied by an increase in the amount of CER as well. As it is known that the higher the level of OUR, the CER is also increasing.

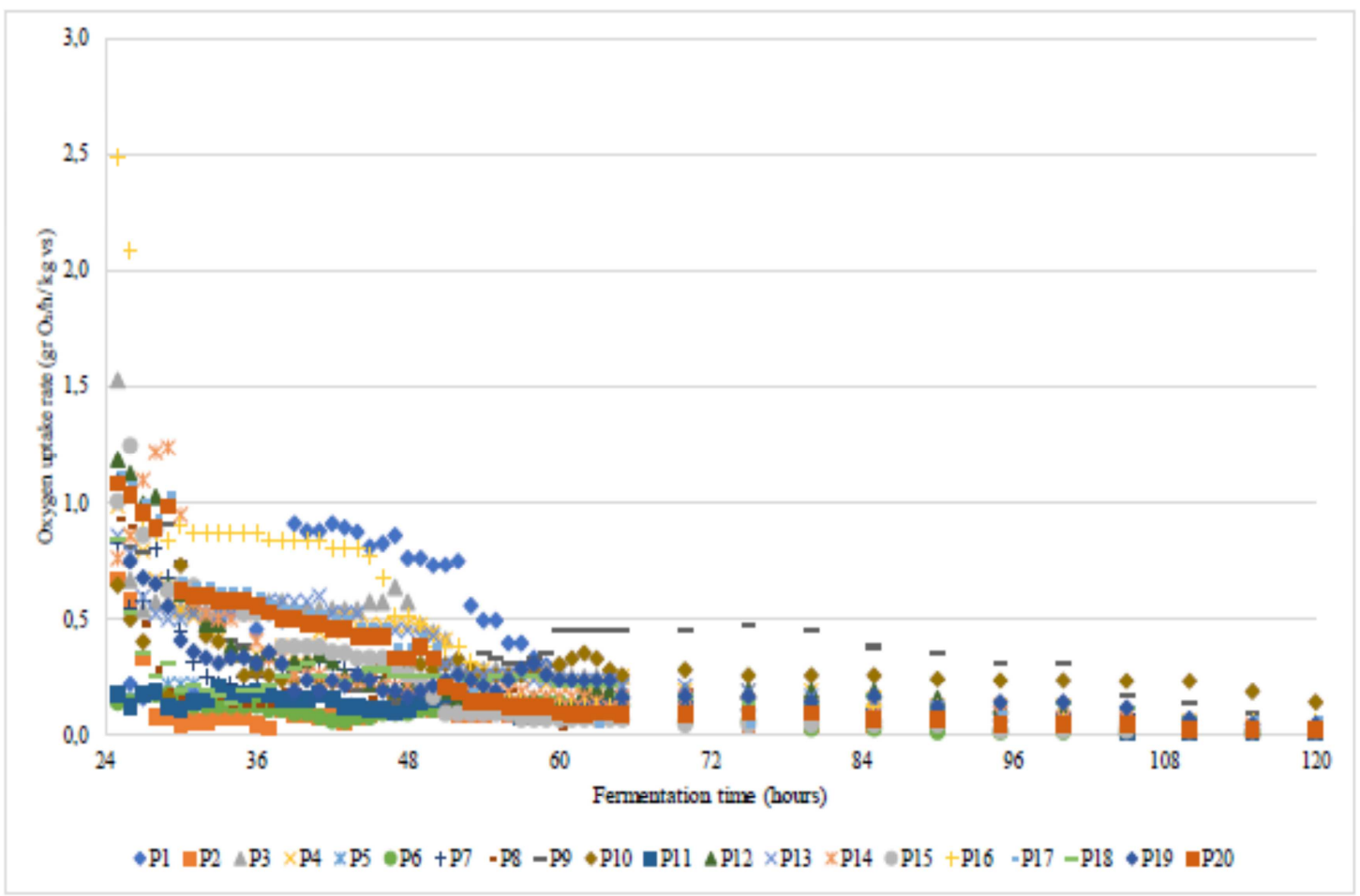

Fig. 2 Oxygen uptake rate (OUR) during fermentation of cocoa beans

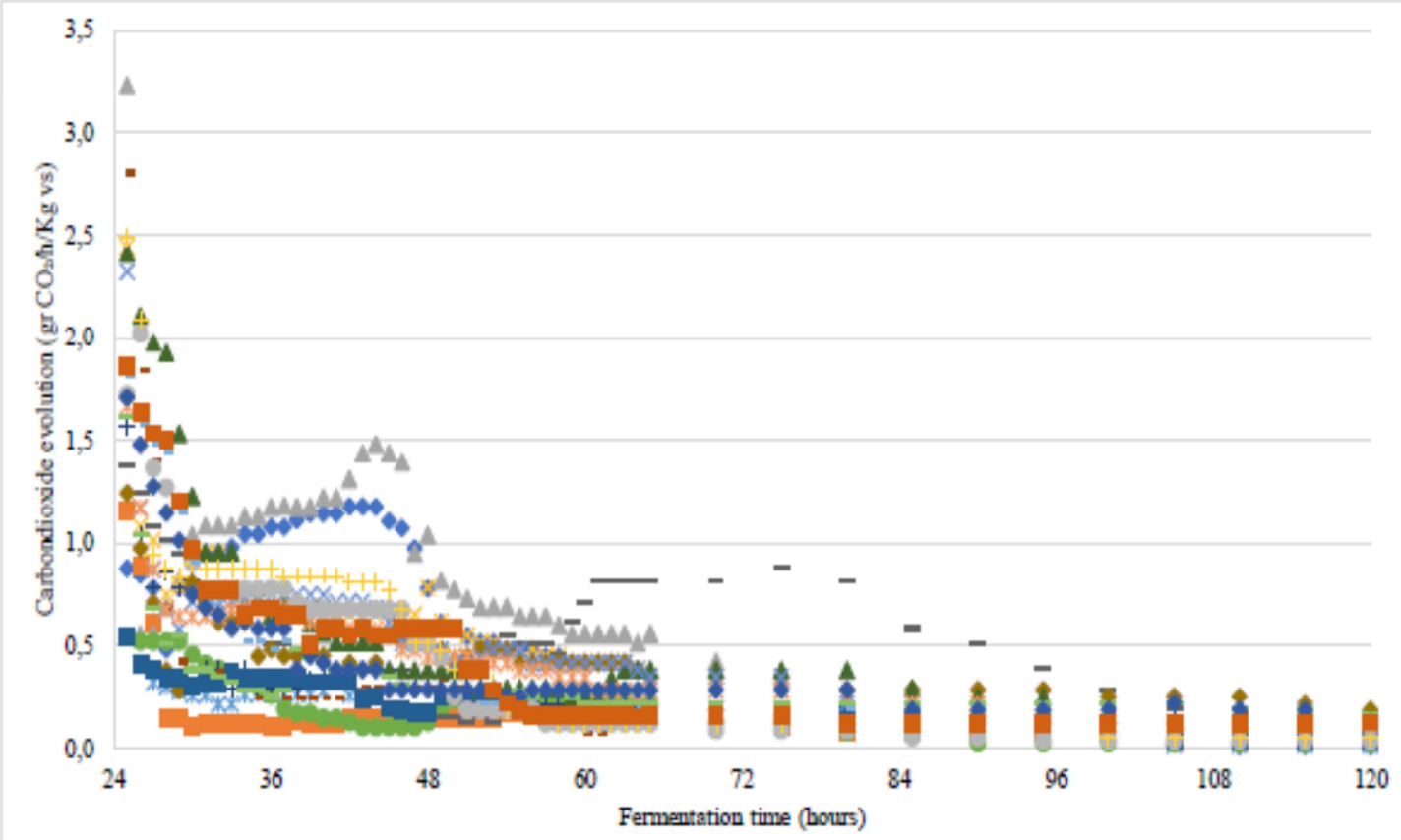

$\diamond \mathrm{P} 1 \square \mathrm{P} 2 \Delta \mathrm{P} 3 \times \mathrm{P} 4 \times \mathrm{P} 5 \bullet \mathrm{P} 6+\mathrm{P} 7=\mathrm{P} 8=\mathrm{P} 9 \diamond \mathrm{P} 10 \square \mathrm{P} 11 \Delta \mathrm{P} 12 \times \mathrm{P} 13 \times \mathrm{P} 14 \circ \mathrm{P} 15+\mathrm{P} 16 \| \mathrm{P} 17=\mathrm{P} 18 \bullet \mathrm{P} 19 \square \mathrm{P} 20$

Fig. 3 Carbon dioxide evolution rate (CER) during the fermentation of cocoa beans 
OUR and CER values are used to determine the cumulative value of oxygen uptake and cumulative carbon dioxide evolution. The experimental values and predictions of the models for cumulative oxygen uptake and cumulative carbon dioxide evolution during fermentation for each treatment are shown in Table 3. Based on Table 3, it is known that the cumulative values of oxygen uptake and cumulative carbon dioxide evolution were obtained through experiments and predictions of the model is good enough. The difference between the average cumulative oxygen uptake value of the experimental results and the predicted impacts of $2.040 \%$, while the difference in the average cumulative value of carbon dioxide evolution from the experimental results and the predicted results of $2.695 \%$.

TABLE III

Cumulative OXYgen Uptake and Cumulative CARbon Dioxide Evolution

\begin{tabular}{|c|c|c|c|c|c|c|c|}
\hline \multirow[t]{2}{*}{ Experiment } & \multirow{2}{*}{$\mathbf{X}_{\mathbf{1}}$} & \multirow{2}{*}{$\mathbf{X}_{2}$} & \multirow{2}{*}{$\mathbf{X}_{3}$} & \multicolumn{2}{|c|}{ Cumulative oxygen uptake, $\mathrm{g} \mathrm{O}_{2}$. $\mathrm{kg}_{\mathrm{vs}}{ }^{-1}\left(\mathrm{Y}_{1}\right)$} & \multicolumn{2}{|c|}{ Cumulative carbon dioxide evolution, $\mathrm{g} \mathrm{CO}_{2 .} \mathrm{kg}_{\mathrm{vs}}^{-1}\left(\mathrm{Y}_{2}\right)$} \\
\hline & & & & Experiment & Prediction & Experiment & Prediction \\
\hline 1 & 1 & 0.2 & 40 & 25.246 & 23.750 & 38.085 & 37.289 \\
\hline 2 & 9 & 0.2 & 40 & 7.271 & 7.949 & 12.152 & 11.303 \\
\hline 3 & 1 & 0.4 & 40 & 25.519 & 28.302 & 50.974 & 53.733 \\
\hline 4 & 9 & 0.4 & 40 & 22.830 & 20.049 & 36.477 & 35.340 \\
\hline 5 & 1 & 0.2 & 60 & 9.923 & 13.396 & 16.060 & 19.134 \\
\hline 6 & 9 & 0.2 & 60 & 6.729 & 4.638 & 13.849 & 13.028 \\
\hline 7 & 1 & 0.4 & 60 & 16.214 & 16.228 & 24.865 & 27.651 \\
\hline 8 & 9 & 0.4 & 60 & 12.830 & 15.018 & 26.405 & 29.138 \\
\hline 9 & 1 & 0.3 & 50 & 34.295 & 29.520 & 50.313 & 42.490 \\
\hline 10 & 9 & 0.3 & 50 & 19.009 & 21.015 & 30.167 & 30.241 \\
\hline 11 & 5 & 0.2 & 50 & 6.664 & 6.100 & 18.002 & 17.394 \\
\hline 12 & 5 & 0.4 & 50 & 15.772 & 13.567 & 40.812 & 33.671 \\
\hline 13 & 5 & 0.3 & 40 & 23.574 & 24.389 & 35.975 & 35.998 \\
\hline 14 & 5 & 0.3 & 60 & 20.281 & 16.697 & 31.592 & 23.820 \\
\hline 15 & 5 & 0.3 & 50 & 16.694 & 19.739 & 26.738 & 31.740 \\
\hline 16 & 5 & 0.3 & 50 & 18.848 & 19.739 & 30.773 & 31.740 \\
\hline 17 & 5 & 0.3 & 50 & 22.025 & 19.739 & 29.966 & 31.740 \\
\hline 18 & 5 & 0.3 & 50 & 17.279 & 19.739 & 26.989 & 31.740 \\
\hline 19 & 5 & 0.3 & 50 & 17.698 & 19.739 & 29.235 & 31.740 \\
\hline 20 & 5 & 0.3 & 50 & 20.353 & 19.739 & 31.241 & 31.740 \\
\hline
\end{tabular}

\section{B. Analysis of Variance Cumulative Oxygen Uptake using Response Surface Methodology (RSM)}

TABLE IV

ANALYSIS VARIAN OF CUMULATIVE OXYGEN UPTAKE IN COCOA BEAN FERMENTATION PROCESS

\begin{tabular}{|c|c|c|c|c|}
\hline Font size & DF & Seq SS & Adj MS & $\mathbf{P}$ \\
\hline Regression & 9 & 819,89 & 91,099 & 0,001 \\
\hline Linier & 3 & 348,90 & 116,299 & 0,002 \\
\hline $\mathrm{X}_{1}$ & & & & 0,003 \\
\hline $\mathrm{X}_{2}$ & & & & 0,001 \\
\hline $\mathrm{X}_{3}$ & & & & 0,546 \\
\hline Square & 3 & 296,95 & 98,984 & 0,004 \\
\hline $\mathrm{X}_{1} * \mathrm{X}_{1}$ & & & & 0,020 \\
\hline $\mathrm{X}_{2} * \mathrm{X}_{2}$ & & & & 0,001 \\
\hline $\mathrm{X}_{3} * \mathrm{X}_{3}$ & & & & 0,697 \\
\hline Interaction & 3 & 54,77 & 18,256 & 0,240 \\
\hline $\mathrm{X}_{1} * \mathrm{X}_{2}$ & & & & 0,140 \\
\hline $\mathrm{X}_{1} * \mathrm{X}_{3}$ & & & & 0,165 \\
\hline $\mathrm{X}_{2} * \mathrm{X}_{3}$ & & & & 0,722 \\
\hline Residual Error & 10 & 110,80 & 11,080 & \\
\hline Lack-of-Fit & 5 & 90,02 & 18,004 & 0,067 \\
\hline Pure Error & 5 & 20,78 & 4,155 & \\
\hline Total & 19 & 930,69 & & \\
\hline $\mathrm{R}-\mathrm{Sq}=88,1 \%$ & & & & \\
\hline
\end{tabular}

Based on the results of the analysis variant of cumulative oxygen uptake shows the R2 value of $88.1 \%$ as shown in Table 4 , indicates that the variables $\mathrm{X} 1, \mathrm{X} 2$, and $\mathrm{X} 3$ have an effect of $88.1 \%$ on the model. The regression value is 0.001 less than the value of the significance level $\alpha=5 \%$, this means that the $X_{1}, X_{2}, X_{3}$ variables determined have an influence on the model produced.

Then in the lack of fit test, the initial hypothesis $\left(\mathrm{H}_{0}\right)$ will be rejected if the P-value is less than $\alpha$ and vice versa the initial hypothesis will fail to reject if the P-value exceeds $\alpha$. ANOVA analysis results (Table 4.) show the value of the lack of fit test is 0.067 because $\alpha$ is $5 \%$. Then there is no reason to reject the initial hypothesis $\left(\mathrm{H}_{0}\right)$, which says there is no lack of fit. When viewed based on the lack of fit value, the resulting model by the cumulative oxygen uptake. The mathematical model obtained to predict this value is:

$$
\begin{array}{cc}
\mathrm{Y}_{1}= & -15,690-8,135 \mathrm{X}_{1}+629,569 \mathrm{X}_{2}- \\
1,280 \mathrm{X}_{3}+0,345 \mathrm{X}_{1} * \mathrm{X}_{1}-990,541 \mathrm{X}_{2} * \mathrm{X}_{2} \\
+0,008 \mathrm{X}_{3} * \mathrm{X}_{3}+4,717 \mathrm{X}_{1} * \mathrm{X}_{2}+0,044 \mathrm{X}_{1} * \mathrm{X}_{3}- \\
0,430 \mathrm{X}_{2} * \mathrm{X}_{3}
\end{array}
$$




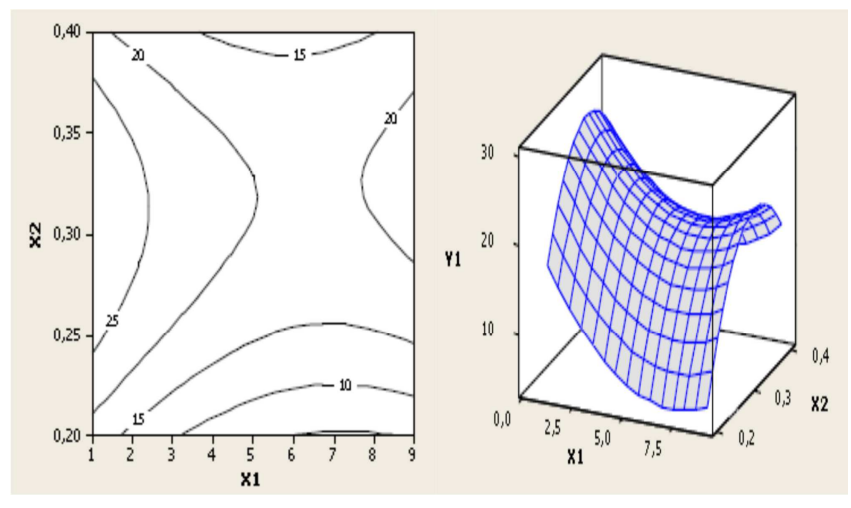

Fig. 4 Plots contour and surface relationships cumulative oxygen uptake $\left(\mathrm{Y}_{1}\right)$ with fruit storage time $\left(\mathrm{X}_{1}\right)$ and aeration rate $\left(\mathrm{X}_{2}\right)$, at a temperature of the fermenter $\left(\mathrm{X}_{3}\right)=50^{\circ} \mathrm{C}$

Based on Fig. 4, it is found that the pod storage before fermentation in 1-3 days with aeration rate of 0.2-0.4 1.mnt-1 results in a higher cumulative oxygen uptake value compared to the pod storage before fermentation in 4-9 day. This can be because pod stored for 1-3 days before fermentation generally has the best condition, with a fresh aroma of pulp. This condition stimulates the growth of microorganisms that play a role during the fermentation process to grow and develop faster so that oxygen consumption becomes higher. Whereas cocoa samples stored for longer usually cause the cocoa beans and pulp to dry somewhat, even with a little mold. So, it is estimated that the growth of microorganisms during fermentation is less due to the low quality of the cocoa pulp [17].

Fig. 5. shows the highest cumulative oxygen uptake of $35.45 \mathrm{~g} \mathrm{O}_{2} \mathrm{~kg}_{\mathrm{vs}}{ }^{-1}$ which is predicted to be obtained at 1-day cocoa fruit storage time and fermented at $40{ }^{\circ} \mathrm{C}$ fermenter temperature and the aeration rate of $0.31 . \mathrm{min}^{-1}$. Based on the contour plots in Fig. 5 it was also shown that the storage time of 1-3 days of cocoa fruit with fermenter temperature $<50{ }^{\circ} \mathrm{C}$ produced a higher cumulative oxygen uptake value.

Furthermore, Fig. 6 shows that the highest cumulative value of oxygen uptake for cocoa fruits stored 5 days before fermentation was obtained at 20-24.65 $\mathrm{g} \mathrm{O}_{2} \mathrm{~kg}_{\mathrm{vs}}^{-1}$ at fermenter temperature conditions $\leq 50^{\circ} \mathrm{C}$ with an aeration rate of $0.25-0,381 . \mathrm{min}^{-1}$. In contrast, the lowest value is 3.72 $\mathrm{g} \mathrm{O}_{2} \mathrm{~kg}_{\mathrm{vs}}{ }^{-1}$ at $60{ }^{\circ} \mathrm{C}$ fermenter temperature, aeration rate 0.2 1. $\mathrm{min}^{-1}$.
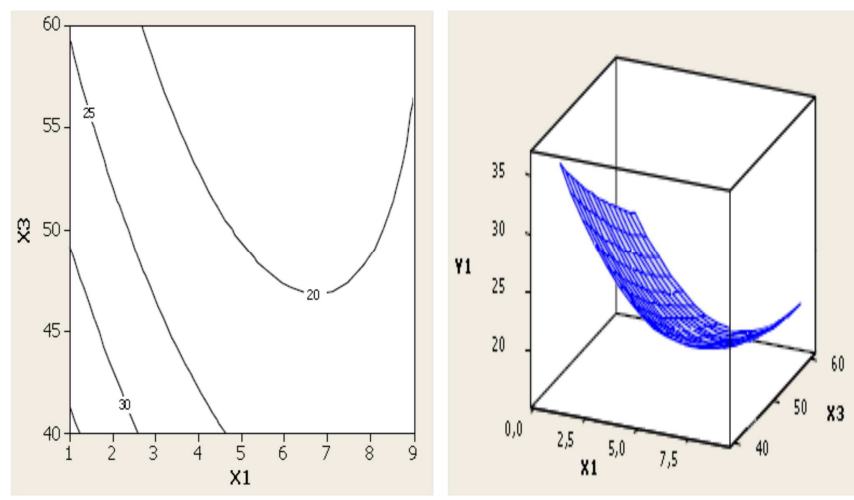

Fig. 5 Plots contour and surface cumulative oxygen uptake relationship with fruit storage time $\left(\mathrm{X}_{1}\right)$, and the temperature of the fermenter $\left(\mathrm{X}_{3}\right)$, the aeration rate $\left(\mathrm{X}_{2}\right)=0.31 \mathrm{~min}^{-1}$
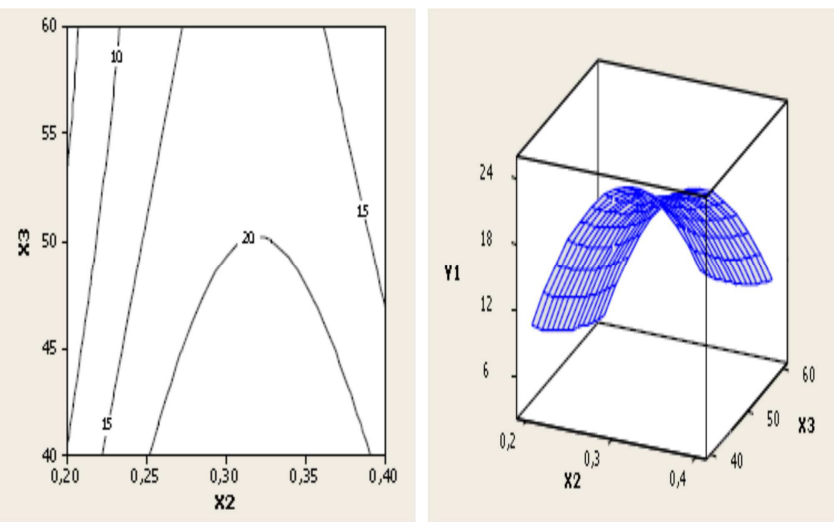

Fig. 6 Plots contour and surface cumulative relationship with the aeration rate of oxygen uptake $\left(\mathrm{X}_{2}\right)$, and the temperature of the fermenter $\left(\mathrm{X}_{3}\right)$, the curing time $\left(\mathrm{X}_{1}\right)=5$ days

Previously it was known that every $100 \mathrm{~kg}$ of cocoa beans needed 700 liters of air for 5-7 days of fermentation, most of which was used on the last 4 days of fermentation. However, the media and fermentation methods are not clearly known and how to determine the amount of aeration [18]. So, if it is considered that the air is in the form of oxygen ( $\rho$ oxygen $=$ $0.00143 \mathrm{~kg} .^{-1}$ ) used during the last 4 days of fermentation, it is estimated that the cocoa bean fermentation process requires a cumulative oxygen uptake of $10.01 \mathrm{~g} \mathrm{O}_{2} \mathrm{~kg}_{\mathrm{vs}}{ }^{-1}$.

\section{Analysis of Variance Cumulative Carbon Dioxide Evolution Using Response Surface Methodology (RSM)}

Based on the analysis of the cumulative carbon dioxide evolution variant during the cocoa bean fermentation process, shown in Table 5 obtained $\mathrm{R}^{2}$ of $87.3 \%$. This indicates that the fixed variables $\left(\mathrm{X}_{1}, \mathrm{X}_{2}\right.$, and $\left.\mathrm{X}_{3}\right)$ have an effect of $87.3 \%$ on cumulative carbon dioxide evolution. Thus, other variables can affect the cumulative carbon dioxide evolution in cocoa bean fermentation in addition to the variables that have been determined, including the process of mixing cocoa beans during fermentation. Stirring aims to uniform changes in fermentation temperature, as well as to increase the success of the fermentation process [19]. Even mixing cocoa beans during fermentation aims to improve aeration and increase the contact area of cocoa beans with air.

TABLE V

ANALYSIS OF THE REGRESSION VARIANT OF CUMULATIVE CARBON DIOXIDE EVOLUTION ON COCOA BEAN FERMENTATION

\begin{tabular}{|l|l|l|l|l|}
\hline Source & DF & Seq SS & Adj MS & P \\
\hline Regression & 9 & 1827.60 & 203.067 & 0.002 \\
\hline Linear & 3 & 1408.25 & 153.673 & 0.015 \\
\hline $\mathrm{X}_{1}$ & & & & 0.005 \\
\hline $\mathrm{X}_{2}$ & & & & 0.030 \\
\hline $\mathrm{X}_{3}$ & & & & 0.714 \\
\hline Square & 3 & 161.51 & 53.836 & 0.175 \\
\hline $\mathrm{X}_{1}{ }^{*} \mathrm{X}_{1}$ & & & & 0.168 \\
\hline $\mathrm{X}_{2} \mathrm{X}_{2}$ & & & & 0.074 \\
\hline $\mathrm{X}_{3} \mathrm{X}_{3}$ & & & & 0.570 \\
\hline Interaction & 3 & 257.84 & 85.948 & 0.070 \\
\hline $\mathrm{X}_{1} * \mathrm{X}_{2}$ & & & & 0.323 \\
\hline $\mathrm{X}_{1} * \mathrm{X}_{3}$ & & & & 0.022 \\
\hline $\mathrm{X}_{2} \mathrm{X}_{3}$ & & & & 0.303 \\
\hline Residual Error & 10 & 266.78 & 26.678 & \\
\hline Lack-of-Fit & 5 & 248.62 & 49.724 & 0.006 \\
\hline Pure Error & 5 & 18.17 & 3.633 & \\
\hline Total & 19 & 2094,39 & & \\
\hline R-Sq = 87,3\% & & & \\
\hline
\end{tabular}


ANOVA analysis results (Table 5.) show that the P-value regression has a value smaller than the significance level $\alpha=$ $5 \%$ so that the resulting model is considered to have an influence on the specified fixed variables. Furthermore, the lack of fit value also shows that the resulting model is quite suitable for cumulative carbon dioxide evolution. The mathematical model obtained is:

$$
\begin{aligned}
& \mathrm{Y}_{2}=-40,532-12,058 \mathrm{X}_{1}+529,187 \mathrm{X}_{2}+ \\
& 1,195 \mathrm{X}_{3}+0,289 \mathrm{X}_{1} * \mathrm{X}_{1}-620,750 \mathrm{X}_{2} * \mathrm{X}_{2}- \\
& 0,018 \mathrm{X}_{3} * \mathrm{X}_{3}+4,746 \mathrm{X}_{1} \mathrm{X}_{2}+0,124 \mathrm{X}_{1} * \mathrm{X}_{3}- \\
& 1,982 \mathrm{X}_{2} * \mathrm{X}_{3}
\end{aligned}
$$

The relationship between cumulative carbon dioxide evolution of cocoa bean fermentation with pod storage before fermentation $\left(\mathrm{X}_{1}\right)$, aeration rate $\left(\mathrm{X}_{2}\right)$, and fermenter temperature $\left(X_{3}\right)$ are shown in Fig. 7-9. Fig. 7, shows that the cumulative carbon dioxide evolution is higher at 1-3 days of cocoa pod storage, compared to 4-9 days of cacao pod storage, with 0.2 to $0.41 . \mathrm{min}^{-1}$ aeration rate, and $50{ }^{\circ} \mathrm{C}$ fermenter temperature.
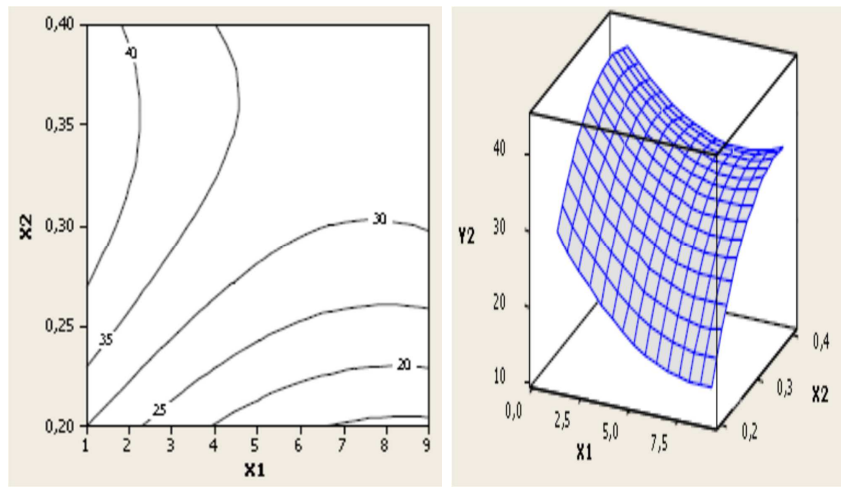

Fig. 7 Plots contour and surface relationships cumulative carbon dioxide evolution with storage time cacao $\left(\mathrm{X}_{1}\right)$ and aeration rate $\left(\mathrm{X}_{2}\right)$, at a temperature of the fermenter $\left(\mathrm{X}_{3}\right)=50^{\circ} \mathrm{C}$.

Furthermore, Fig. 8 shows that the highest prediction of cumulative carbon dioxide evolution value is $51.22 \mathrm{~g} \mathrm{CO}_{2}$ $\mathrm{kg}_{\mathrm{vs}}{ }^{-1}$ obtained at 1-day cocoa fruit storage time, fermenter temperature $40{ }^{\circ} \mathrm{C}$, at aeration rate $0.31 . \mathrm{min}^{-1}$. In comparison, the lowest cumulative carbon dioxide evolution value is $23.82 \mathrm{~g} \mathrm{CO}_{2} \mathrm{kgvs}^{-1}$ with 5.6 days of cocoa fruit storage time, $60{ }^{\circ} \mathrm{C}$ fermenter temperature, and $0.31 . \mathrm{min}^{-1}$ aeration rate.
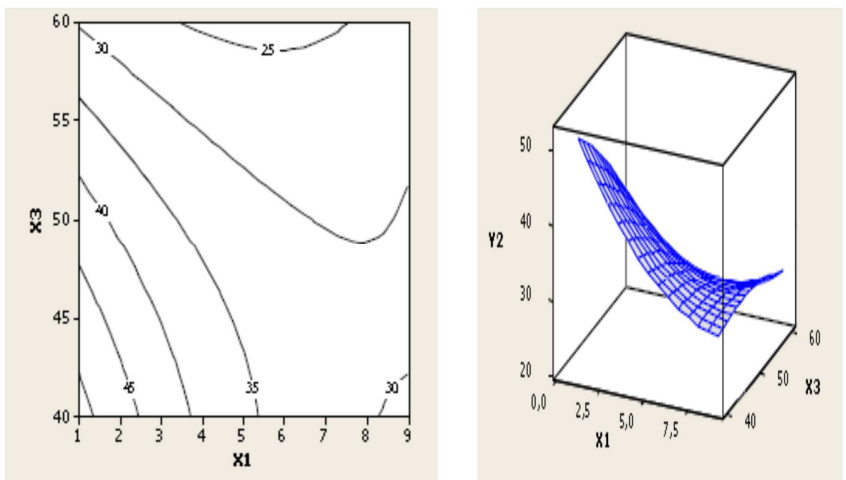

Fig. 8. Plots contour and surface relationships cumulative carbon dioxide evolution with storage time cacao (X1), and the temperature of the fermenter $(\mathrm{X} 3)$, the aeration rate $(\mathrm{X} 2)=0.31 \cdot \mathrm{min}^{-1}$.
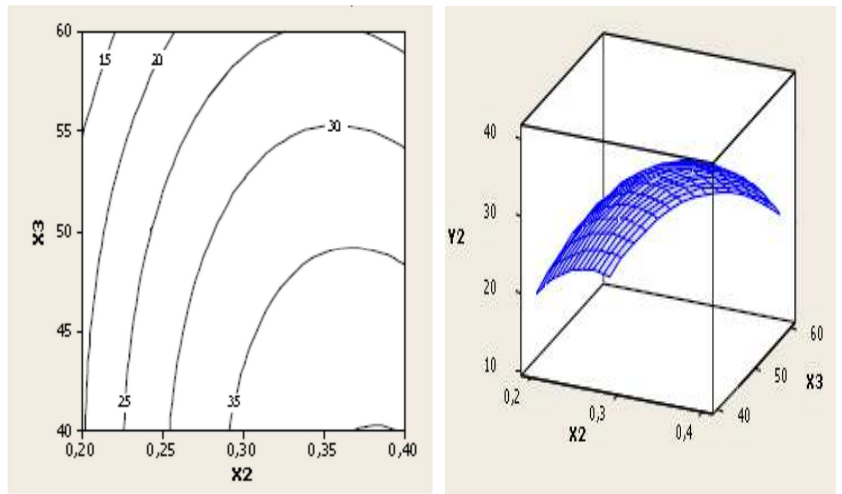

Fig. 9 Plot contours and surface cumulative carbon dioxide evolution relationship with aeration rate $\left(\mathrm{X}_{2}\right)$, and the temperature of the fermenter $\left(X_{3}\right)$ at the time of the cocoa fruit storage $\left(X_{1}\right)=5$ days.

Fig. 9 also shows that cocoa fruit stored for 5 days results in the highest cumulative carbon dioxide evolution value of $40.05 \mathrm{~g} \mathrm{CO}_{2} \mathrm{Kg}_{\mathrm{vs}}{ }^{-1}$, at a fermenter temperature of $40^{\circ} \mathrm{C}$, and an aeration rate of $0.3751 . \mathrm{min}^{-1}$. At the same time, the lowest cumulative carbon dioxide evolution value is $11.56 \mathrm{~g} \mathrm{CO}_{2} \mathrm{~kg}_{\mathrm{vs}}^{-1}$, at a fermenter temperature of $60^{\circ} \mathrm{C}$, and an aeration rate of $0.21 . \mathrm{min}^{-1}$. Besides, the sample with a $60{ }^{\circ} \mathrm{C}$ fermenter temperature treatment at the end of the fermentation process produces more water (a product of the respiration process), as well as drier cocoa beans and cocoa pulp.

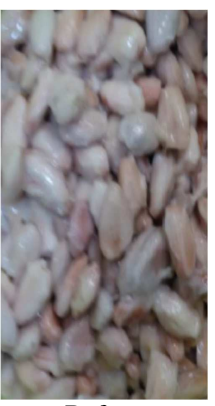

Before

fermentation

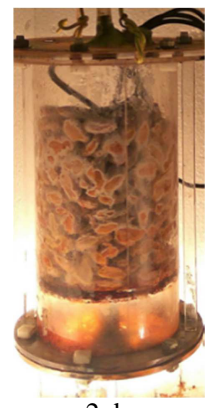

2 days

fermentation

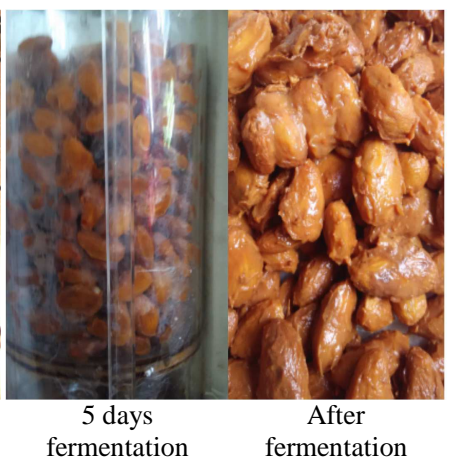

fermentation
Fig. 10. Changes in cocoa beans during fermentation

The results show that pod storage, aeration rate, and fermenter temperature affected the cumulative oxygen uptake and cumulative carbon dioxide evolution. Surface and contour plot analysis (Fig. 4-9) show that the highest of cumulative oxygen uptake and cumulative carbon dioxide evolution (5 days fermentation) was $35.45 \mathrm{gO}_{2} \cdot \mathrm{kg}_{\mathrm{vs}}{ }^{-1}$ and $51.22 \mathrm{gCO}_{2} \cdot \mathrm{kg}_{\mathrm{vs}}{ }^{-1}$, which pod storage of 1 day, aeration rate of 0.3 liters/minute and fermenter temperature of $40{ }^{\circ} \mathrm{C}$. Meanwhile, the lowest cumulative oxygen uptake and cumulative carbon dioxide evolution were $3.55 \mathrm{gO}_{2} \cdot \mathrm{kg}_{\mathrm{vs}}{ }^{-1}$ and $11.62 \mathrm{gCO}_{2} \cdot \mathrm{kg}_{\mathrm{vs}}{ }^{-1}$, which pod storage of 5 days, aeration rate of 0.2 liters/minute and fermenter temperature of $60{ }^{\circ} \mathrm{C}$. Besides, the success of the fermentation process is characterized by changes color of the cocoa pulp from white to brown, as shown in Fig. 10.

\section{CONCLUSION}

Cumulative oxygen uptake and cumulative carbon dioxide evolution values during the fermentation process using 
response surface methodology were obtained, respectively 6.66-34.29 $\mathrm{g} \mathrm{O}_{2} \mathrm{~kg}_{\mathrm{vs}}{ }^{1}$ and 12.15-50.97 $\mathrm{g} \mathrm{CO}_{2} \mathrm{~kg}_{\mathrm{vs}}{ }^{1}$ at various treatments. The highest amount of oxygen consumption and carbon dioxide production is generally obtained in the sample with the treatment time of cocoa fruit storage stored for 5 days, aeration rate $0.25-0.41 . \mathrm{min}^{-1}$, and fermenter temperature $\leq 50^{\circ} \mathrm{C}$.

\section{NOMENCLATURE}

$\mathrm{CO}_{2} \quad$ oxygen concentration by mass $\left(\mathrm{gm}^{-3}\right)$

$\mathrm{MO}_{2} \quad$ the molecular mass of oxygen $\left(32 \mathrm{gmol}^{-1}\right)$

$\mathrm{P} \quad$ atmosphere pressure $(101325 \mathrm{~Pa})$

$\mathrm{CO}_{2 \text { vol }} \quad$ oxygen concentration by percent volume (\%)

$\mathrm{R}$ the gas constant $\left(8,314472 \mathrm{Jmol}^{-1} \mathrm{~K}^{-1}\right)$

$\mathrm{T} \quad$ inlet/outlet air temperature $\left({ }^{\circ} \mathrm{C}\right)$

OUR oxygen uptake rate (consumption $\left.\mathrm{O}_{2}\right)\left(\mathrm{gh}^{-1} \mathrm{~kg}^{-1}\right)$

$\mathrm{Q} \quad$ airflow rate $\left(\mathrm{m}^{3} \mathrm{~h}^{-1}\right)$

$\mathrm{CO}_{2 \mathrm{a}} \quad$ average oxygen concentration of ambient air $\left(\mathrm{mg}^{-3}\right)$

$\mathrm{VS}_{0} \quad$ Volatile solid initial $(\mathrm{kg})$.

$\mathrm{CCO}_{2} \quad$ carbon dioxide concentration $\left(\mathrm{gm}^{-1}\right)$

$\mathrm{MCO}_{2}$ the molecular mass of carbon dioxide (44 $\left.\mathrm{gmol}^{-1}\right)$

$\mathrm{CCO}_{2 \text { vol }}$ carbon dioxide concentration by percent volume $(\%)$

CER carbon dioxide rate $\left(\mathrm{gh}^{-1} \mathrm{~kg}^{-1}\right)$

$\mathrm{CCO}_{2 \mathrm{a}}$ the average concentration of carbon dioxide in ambient air $\left(\mathrm{mg}^{-3}\right)$

$\mathrm{Y}$ the value of the treatment response to cumulative oxygen uptake $\left(\mathrm{Y}_{1}\right)$ and cumulative carbon dioxide evolution $\left(\mathrm{Y}_{2}\right)$ during the fermentation process $\left(\mathrm{g} \mathrm{O}_{2}\right.$ or $\left.\mathrm{CO}_{2} \mathrm{kgvs}^{-1}\right)$

$\beta_{0} \quad$ intercept/constant

$\beta_{1}, \beta_{2}, \beta_{3} \quad$ linear coefficients,

$\beta_{11}, \beta_{22}, \beta_{33}$ quadratic coefficients

$\beta_{12}, \beta_{13}, \beta_{23}$ treatment interaction coefficients.

\section{ACKNOWLEDGMENT}

We are grateful to the support from the Ministry of Education and Culture, and to Mr. Dualim Atma Dewangga who helped us a lot in laboratory activities.

\section{REFERENCES}

[1] Kongor, J. E., Hinneh, M., de Walle, D. Van, Afoakwa, E. O., Boeckx, P., \& Dewettinck, K. (2016). Factors influencing quality variation in cocoa (Theobroma cacao) bean flavour profile - A review. Food Research International, 82, 44-52. https://doi.org/10.1016/j.foodres.2016.01.012

[2] Ho, V. T. T., Zhao, J., \& Fleet, G. (2015). International Journal of Food Microbiology The effect of lactic acid bacteria on cocoa bean fermentation. International Journal of Food Microbiology, 205, 5467. https://doi.org/10.1016/j.ijfoodmicro.2015.03.031

[3] Sulaiman, K. B., \& Yang, T. A. (2015). Color Characteristics of Dried Cocoa Using Shallow Box Fermentation Technique, 9(12), 1277-1281.

[4] Misnawi. (2008). Physico-Chemical Changes During Cocoa Fermentation and Key Enzymes Involved. Review Penelitian Kopi Dan Kakao, 24(1), 47-64.
[5] Schwan, R. F., \& Wheals, A. E. (2004). The microbiology of cocoa fermentation and its role in chocolate quality. Critical Reviews in Food Science and Nutrition, 44(4), 205-221. https://doi.org/10.1080/10408690490464104

[6] Menezes, A. G. T., Batista, N. N., Ramos, C. L., de Andrade e Silva, A. R., Efraim, P., Pinheiro, A. C. M., \& Schwan, R. F. (2016). Investigation of chocolate produced from four different Brazilian varieties of cocoa (Theobroma cacao L.) inoculated with Saccharomyces cerevisiae. Food Research International, 81, 83-90. https://doi.org/10.1016/j.foodres.2015.12.036

[7] Kadow, D., Bohlmann, J., Phillips, W., \& Lieberei, R. (2013). Identification of main fine or flavour components in two genotypes of the cocoa tree (Theobroma cacao L.). Journal of Applied Botany and Food Quality, 86, 90-98. https://doi.org/10.5073/JABFQ.2013.086.013

[8] Afoakwa, E. O., Kongor, J. E., Takrama, J., \& Budu, A. S. (2013). Changes in nib acidification and biochemical composition during fermentation of pulp pre-conditioned cocoa (theobroma cacao) beans. International Food Research Journal, 20(4), 1843-1853.

[9] Krähmer, A., Engel, A., Kadow, D., Ali, N., Umaharan, P., Kroh, L. W., \& Schulz, H. (2015). Fast and neat - Determination of biochemical quality parameters in cocoa using near infrared spectroscopy. Food Chemistry, 181, 152-159. https://doi.org/10.1016/j.foodchem.2015.02.084

[10] Kadow, D., Niemenak, N., Rohn, S., \& Lieberei, R. (2015). LWT Food Science and Technology Fermentation-like incubation of cocoa seeds (Theobroma cacao L.) e Reconstruction and guidance of the fermentation process. LWT - Food Science and Technology, 62(1), 357-361. https://doi.org/10.1016/j.lwt.2015.01.015

[11] Aryanti, M. (2017). Karakteristik Mutu Biji Kakao (Theobroma Cacao L) Dengan Perlakuan Waktu Fermentasi Berdasar SNI 23232008 Quality Characteristics of Cocoa Beans (Theobroma cacao L) With Time Fermentation Treatment Based on ISO 2323-2008. Jurnal Industri Hasil Perkebunan Vol. 12 No. 1 Juni 2017, 34-42.

[12] Hernández, C. H.-, López-andrade, P. A., Ramírez-guillermo, M. A., Ramírez, D. G., \& Pérez, J. F. C. (2018). Evaluation of different fermentation processes for use by small cocoa growers in mexico Evaluation of different fermentation processes for use by small cocoa growers in mexico, (January). https://doi.org/10.1002/fsn3.333

[13] Saludes, R. B., Iwabuchi, K., Kayanuma, A., \& Shiga, T. (2007). Composting of dairy cattle manure using a thermophilic-mesophilic sequence. Biosystems Engineering, 98(2), 198-205. https://doi.org/10.1016/j.biosystemseng.2007.07.003

[14] Fonseca, S. C., Oliveira, F. A. R., \& Brecht, J. K. (2002). Modelling respiration rate of fresh fruits and vegetables for modified atmosphere packages: A review. Journal of Food Engineering, 52(2), 99-119. https://doi.org/10.1016/S0260-8774(01)00106-6

[15] Bezerra, M. A., Santelli, R. E., Oliveira, E. P., Villar, L. S., \& Escaleira, L. A. (2008). Response surface methodology (RSM) as a tool for optimization in analytical chemistry. Talanta, 76(5), 965-977. https://doi.org/10.1016/j.talanta.2008.05.019

[16] Hartuti, S., \& Supardan, M. D. (2013). Optimasi ekstraksi gelombang ultrasonik untuk produksi oleoresin jahe (Zingiber officinale Roscoe) menggunakan Response Surface Methodology (RSM). Agritech, 33(4), 415-423.

[17] Hartuti, S., Bintoro, N., Karyadi, J. N. W., \& Pranoto, Y. (2019). Analysis of cumulative oxygen uptake in cocoa beans (Theobroma cacao L.) fermentation using packed bed reactor. IOP Conf. Ser.:

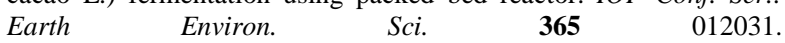
https://iopscience.iop.org/article/10.1088/1755-1315/365/1/012031

[18] SCCP-Swisscontact. (2013). Pasca panen, kualitas biji kakao \& fermentasi. Medan, Indonesia.

[19] Aka S. Koffi, N'Goran Yao, Philippe Bastide, Denis Bruneau, D. K. (2017). Homogenization of Cocoa Beans Fermentation to Upgrade Quality Using an Original Improved Fermenter. International Journal of Nutrion and Food Engineering, 11(7), 558-563. 